\title{
Phytoprotection
}

\section{Effectiveness of fungicidal seed treatments applied to smooth or shrivelled soybean seeds contaminated by Diaporthe phaseolorum}

\section{R. Hall et A.G. Xue}

Volume 76, numéro 2, 1995

URI : https://id.erudit.org/iderudit/706084ar

DOI : https://doi.org/10.7202/706084ar

Aller au sommaire du numéro

Éditeur(s)

Société de protection des plantes du Québec (SPPQ)l

ISSN

0031-9511 (imprimé)

1710-1603 (numérique)

Découvrir la revue

Citer cet article

Hall, R. \& Xue, A. (1995). Effectiveness of fungicidal seed treatments applied to smooth or shrivelled soybean seeds contaminated by Diaporthe phaseolorum. Phytoprotection, 76(2), 47-56. https://doi.org/10.7202/706084ar
Résumé de l'article

On a examiné l'effet de 11 fongicides sur six lots de semences de soja (Glycinemax) provenant de l'Ontario en 1986-1987 et contaminés par le Diaporthe phaseolorum var. caulivora (7-76 \%) et le D. phaseolorum var. sojae(5-19\%). Le Phomopsis longicolla a également contaminé trois de ces lots à de faibles taux (1-2 \%). Le fongicide Vitaflo-280®, un mélange de carbathiine et de thirame, appliqué à trois lots de semences décolorées et ridées, a augmenté l'émergence des plantules de soja, la densité du peuplement à la récolte et le rendement en grain, et a diminué la gravité de l'infection des tiges. Il a été inefficace lorsqu'appliqué à trois lots de semences brillantes et lisses. Il n'existait pas de rapport entre l'efficacité de ce produit et le degré de contamination des semences. Dix autres produits fongicides ont aussi été respectivement efficaces et inefficaces lorsqu'appliqués à des lots de semences ridées et lisses. Les matières actives les plus efficaces ont été le thirame, la carbathiine le bénomyl et le captane, et les produits commerciaux les plus efficaces disponibles en Ontario ont été le Vitaflo- $280 ®$, le Vitavax $P \circledast$, le Thiram 320F® et l'Anchor ${ }^{\circledR}$. L'augmentation maximale du rendement en grain a été $60,5 \%$. 


\title{
Effectiveness of fungicidal seed treatments applied to smooth or shrivelled soybean seeds contaminated by Diaporthe phaseolorum
}

\author{
Robert Hall ${ }^{1}$ and Allen G. Xue ${ }^{2}$
}

Received 1994-08-26; accepted 1995-10-19

The effect of 11 fungicides on six lots of soybean (Glycine max) seed produced in Ontario in 1986-1987 and contaminated with Diaporthe phaseolorum var. caulivora $(7-76 \%)$ and $D$. phaseolorum var. sojae (5-19\%) was examined. Phomopsis longicolla also contaminated three of these seed lots at low rates (1-2\%). The fungicide Vitaflo-280 ${ }^{\circ}$, a mix of carbathiin and thiram, increased soybean seedling emergence, plant stand at harvest and seed yield, and decreased the severity of stem infection when applied to three lots of discolored and shrivelled seed, but was ineffective when applied to three lots of bright and smooth seed. The effectiveness of this product was not related to the incidence of contaminated seed. A further 10 fungicidal products were similarly effective and ineffective when applied to shrivelled and smooth seed lots, respectively. The most effective active ingredients were thiram, carbathiin, benomyl and captan, and the most effective commercial products available in Ontario were Vitaflo-280 $\AA$, Vitavax $P \AA$, Thiram $320 F \AA$, and Anchor ${ }^{\circledR}$. The maximum increase in seed yield was $60.5 \%$.

Hall, R. et A.G. Xue. 1995. Efficacité de fongicides appliqués à des semences de soja lisses ou ridées contaminées par le Diaporthe phaseolorum. PHYTOPROTECTION 76 : 47-56.

On a examiné l'effet de 11 fongicides sur six lots de semences de soja (Glycine max) provenant de l'Ontario en 1986-1987 et contaminés par le Diaporthe phaseolorum var. caulivora (7-76 \%) et le D. phaseolorum var. sojae (5-19\%). Le Phomopsis longicolla a également contaminé trois de ces lots à de faibles taux (1-2\%). Le fongicide Vitaflo-280®, un mélange de carbathiine et de thirame, appliqué à trois lots de semences décolorées et ridées, a augmenté l'émergence des plantules de soja, la densité du peuplement à la récolte et le rendement en grain, et a diminué la gravité de l'infection des tiges. II a été inefficace lorsqu'appliqué à trois lots de semences brillantes et lisses. II n'existait pas de rapport entre l'efficacité de ce produit et le degré de contamination des semences. Dix autres produits fongicides ont aussi été respectivement efficaces et inefficaces lorsqu'appliqués à des lots de semences ridées et lisses. Les matières actives les plus efficaces ont été le thirame, la carbathiine, le bénomyl et le captane, et les produits commerciaux les plus efficaces disponibles en Ontario ont été le Vitaflo-280®, le Vitavax $P \AA$, le Thiram 320F ${ }^{\circledR}$ et l'Anchor ${ }^{\circledR}$. L'augmentation maximale du rendement en grain a été $60,5 \%$.

1. Department of Environmental Biology, University of Guelph, Guelph, Ontario, Canada N1G 2W1

2. Research Centre, Agriculture and Agri-Food Canada, Unit 100, 101 Route 100, Morden, Manitoba, Canada R6M 1 Y5 


\section{INTRODUCTION}

Diaporthe phaseolorum (Cooke \& Ellis) Sacc. var. caulivora Athow \& Caldwell (Dpc), Diaporthe phaseolorum (Cooke \& Ellis) Sacc. var. sojae (Lehman) Wehm. (Dps), and Phomopsis longicolla Hobbs (PI) are seedborne fungal pathogens associated with seed decay, seedling blight, pod and stem blight and stem canker of soybean [Glycine max (L.) Merr.] (Sinclair and Backman 1989). This group of fungi, referred to here as the D-P complex, can reduce plant stand, and seed yield and quality at harvest. The infection of soybean seeds in Ontario by the D-P complex has been reported over a period of more than $40 \mathrm{yr}$ and occasionally (Wallen 1960) has led to an inadequate supply of high quality seed for sowing. Early reports of the disease in Ontario either did not identify the causal organism to species (Hildebrand and Koch 1950) or did not distinguish among Dpc, Dps and PI (Hildebrand and Koch 1947; Wallen 1960; Wallen and Seaman 1963). In a more recent study, Anderson (1985) identified Dpc, but did not differentiate Dps from PI.

Wet weather during seed development and maturation of soybean in Ontario (Canada) in 1986 favoured seed contamination by the D-P complex pathogens. In controlled environments, infected seeds emerged poorly and produced diseased plants (Hall and Guoxing 1987). The purpose of this study was (i) to determine which members of the D-P complex occurred on soybean seed in the province, (ii) to compare the effectiveness of fungicidal seed treatments, including commercial products available in Ontario and experimental formulations, in reducing disease and protecting yield potential in the field, and (iii) to examine the influence of seed quality on the effectiveness of these products ${ }^{1}$.

\section{MATERIALS AND METHODS}

\section{Seed contamination}

Six lots of soybean seed from Ontario were examined, four of cv. Maple Arrow and two of cV. KG-30 (Table 1). Seeds in lots 2, 4, and 6 were bright, smooth and of normal shape and color for the cultivar. Seeds in lots 1, 3, and 5 were discolored and shrivelled.

To determine the incidence of contamination of seed by Dpc, Dps, and PI, 300 seeds from each lot were placed without surface sterilization onto potato dextrose agar (PDA) acidified to $\mathrm{pH} 4$ with lactic acid in 9-cm-diam petri dishes. The dishes vvere incubated in darkness for $7 d$ at $23^{\circ} \mathrm{C}$ and then exposed to a $12-\mathrm{h}$ photoperiod provided by fluorescent and long-wave ultraviolet lamps $(300 \mu \mathrm{mol}$

Table 1. Incidence of contamination of six lots of soybean seed from Ontario by Diaporthe phaseolorum var. caulivora (Dpc), D. phaseolorum var. sojae (Dps), and Phomopsis longicolla (PI)

\begin{tabular}{|c|c|c|c|c|c|c|}
\hline \multirow[b]{2}{*}{ Seed lot } & \multirow[b]{2}{*}{ Cultivar } & \multirow[b]{2}{*}{ Harvest year } & \multirow{2}{*}{$\begin{array}{l}\text { Visual } \\
\text { appearance }\end{array}$} & \multicolumn{3}{|c|}{$\begin{array}{c}\text { Incidence of } \\
\text { contaminated seed } \\
(\%) \dagger\end{array}$} \\
\hline & & & & $\mathrm{Dpc}$ & Dps & $\mathrm{Pl}$ \\
\hline 1 & Maple Arrow & 1986 & Shrivelled & 17 & 19 & 2 \\
\hline 2 & Maple Arrow & 1986 & Smcioth & 7 & 9 & 0 \\
\hline 3 & KG-30 & 1986 & Shrivelled & 11 & 5 & 1 \\
\hline 4 & KG-30 & 1986 & Smcioth & 13 & 5 & 0 \\
\hline 5 & Maple Arrow & 1986 & Shrivelled & 76 & 8 & 1 \\
\hline 6 & Maple Arrow & 1987 & Smcioth & 8 & 10 & 0 \\
\hline
\end{tabular}

$\dagger$ Percentage based on one sample of 300 seeds per lot.

1. The use of trade names in this article does not imply endorsement of any product named or criticism of similar ones not mentioned. 
$\left.\mathrm{m}^{-2} \mathrm{~s}^{-1} \mathrm{PAR}\right)$ for a further $7 \mathrm{~d}$ at $23^{\circ} \mathrm{C}$. Putative colonies of Dpc, Dps, and PI growing from seed were transferred to carnation (Dianthus caryophyllus L.) leafPDA (Fisher et al. 1982) to stimulate production of reproductive structures and incubated as above for $2 \mathrm{wk}$. The fungi were identified according to descriptions provided by Sinclair and Backman (1989). Colony morphologies within each taxon were similar on PDA, acidified PDA and carnation leaf-PDA.

\section{Fungicides}

The fungicides used in this study consisted of eight products commercially available in Ontario and identified by trade name, and three experimental formulations identified by code (Table 2). The products are based on five active ingredients widely used, alone or in combination, for seed treatments in several crops including soybean (McGee 1986). These active ingredients are benomyl [methyl 1-(butylcarbamoyl)benzimidazol-2-ylcarbamate], captan [N-(trichloromethylthio)cyclohex-4-ene1,2-dicarboximide], carbathiin (5,6- dihydro-2-methyl-1,4-oxathi-ine-3carboxanilide), thiabendazole [2-(thiazol4-yl)benzimidazole], and thiram (tetramethylthiuram disulphide). The products, active ingredients, and formulations are listed in Table 2.

\section{Fungitoxicity}

Fungitoxicity in vitro was determined against one isolate each of Dpc and Dps. Each isolate was originally produced from a single conidium derived from colonies isolated from seed of cv. Maple Arrow in 1986. Concentrations of $0,0.01,0.1,1.0$, 10,100 and $1000 \mathrm{mg} \mathrm{L}^{-1}$ of fungicide product were prepared in $0.17 \%$ water agar. The fungicide suspensions were diluted 10 -fold in molten PDA at $50^{\circ} \mathrm{C}$ and the mixture was poured into 9-cm-diam petri dishes. Plugs 5-mm-diam from growing cultures on PDA were placed in the centre of three replicate dishes for each fungicide concentration. Colony width was measured along two perpendicular diameters after incubation of the dishes for $7 \mathrm{~d}$ at $25^{\circ} \mathrm{C}$ in darkness. The percentage inhibition of growth by a fungicide treatment was calculated with Eq. [1].

$$
\begin{aligned}
& \% \text { growth } \\
& \text { inhibition }
\end{aligned}=\frac{\left(\begin{array}{c}
\text { growth in } \\
\text { control }
\end{array}-\begin{array}{c}
\text { growth in } \\
\text { treatment }
\end{array}\right)}{\text { growth in control }} \times 100
$$

Table 2. Product information on fungicides used in soybean seed treatment

\begin{tabular}{|c|c|c|c|c|}
\hline \multicolumn{2}{|c|}{ Product } & \multicolumn{3}{|c|}{ Active ingredient } \\
\hline Trade name & Formulationt & $\begin{array}{l}\text { Common } \\
\text { name }\end{array}$ & Concentration & $\begin{array}{l}\text { Application rate } \\
\text { (g a.i. } \mathrm{kg}^{-1} \text { seed) }\end{array}$ \\
\hline Thiram 75WP & WP & thiram & $75.0 \%$ & 1.05 \\
\hline Thiram 320F & $\mathrm{F}$ & thiram & $32.0 \%$ & 2.33 \\
\hline UBI-1373 & $P$ & carbathiin & $75.0 \%$ & 0.55 \\
\hline Vitaflo-250 & $\mathrm{F}$ & carbathiin & $25.3 \%$ & 0.63 \\
\hline Benlate 50WP & WP & benomyl & $50.0 \%$ & 2.50 \\
\hline Captan & $\mathrm{P}$ & captan & $50.0 \%$ & 0.50 \\
\hline Vitaflo-280 & $\mathrm{F}$ & $\begin{array}{l}\text { carbathiin } \\
\text { thiram }\end{array}$ & $\begin{array}{l}14.9 \% \\
13.2 \%\end{array}$ & $\begin{array}{l}0.39 \\
0.34\end{array}$ \\
\hline Vitavax $\mathrm{P}$ & $\mathrm{P}$ & $\begin{array}{l}\text { carbathiin } \\
\text { thiram }\end{array}$ & $\begin{array}{l}26.7 \% \\
38.8 \%\end{array}$ & $\begin{array}{l}0.69 \\
1.01\end{array}$ \\
\hline Anchor & $\mathrm{F}$ & $\begin{array}{l}\text { carbathiin } \\
\text { thiram }\end{array}$ & $\begin{array}{l}66.7 \mathrm{~g} \mathrm{~L}^{-1} \\
66.7 \mathrm{~g} \mathrm{~L}^{-1}\end{array}$ & $\begin{array}{l}1.00 \\
1.00\end{array}$ \\
\hline UBI-2467 & $\mathrm{F}$ & $\begin{array}{l}\text { carbathiin } \\
\text { thiram }\end{array}$ & $\begin{array}{l}220.0 \mathrm{~g} \mathrm{~L}^{-1} \\
220.0 \mathrm{~g} \mathrm{~L}^{-1}\end{array}$ & $\begin{array}{l}0.55 \\
0.55\end{array}$ \\
\hline UBI-2393 & $\mathrm{F}$ & $\begin{array}{l}\text { thiabendazole } \\
\text { thiram }\end{array}$ & $\begin{array}{r}24.0 \mathrm{~g} \mathrm{~L} \mathrm{~L}^{-1} \\
220.0 \mathrm{~g} \mathrm{~L}^{-1}\end{array}$ & $\begin{array}{l}0.06 \\
0.55\end{array}$ \\
\hline
\end{tabular}

†F : flowable; $P$ : powder; WP : wettable powder. 
The concentration of fungicide product required to inhibit growth by $50 \%$ (EC50) was determined from a plot of the probit value of percentage inhibition against the logarithm of the concentration of fungicide. EC50 values of active ingredients were calculated from EC50 values of commercial formulations containing that one active ingredient only.

\section{Seed treatments}

The effects of seed treatment on emergence, stand at harvest, disease index, yield, and 1000-seed wt were assessed in four trials over $2 \mathrm{yr}$. Trials $1-3$ were conducted in 1987 with seed lots 1-5 and trial 4 was conducted in 1988 with seed lot 6 . The fungicide Vitaflo-280 alone was tested in trials 1 and 2, and all 11 products were tested in trials 3 and 4 . Seeds were treated $3 \mathrm{~d}$ before sowing. Fungicide was added to $200 \mathrm{~g}$ of seed in glass jars and the jars were shaken vigorously after the addition of the fungicides to ensure uniform coverage of the seeds. Seeds were sown $4 \mathrm{~cm}$ deep in clay loam soil at the Arkell Research Station, Arkell, Ontario (lat. $43^{\circ} 24^{\prime} \mathrm{N}$ long. $80^{\circ} 6^{\prime} \mathrm{W}$ ) on 22 May 1987 and on 25 May 1988. Plots contained one row $5 \mathrm{~m}$ long sown with 100 seed, and were separated by two guard rows (sown with bright, smooth seed of cv. Maple Arrow treated with the fungicide Vitaflo-280). Rows were $0.53 \mathrm{~m}$ apart. In trials 1 and 2, a split-plot design with four replicates was used in which seed lot and fungicide treatment were assigned to main plots and subplots, respectively. A randomized complete block design with four replicates was used in trials 3 and 4 . Seedling emergence, including live and dead plants, was counted $14 \mathrm{~d}$ after sowing and surviving plants were counted at harvest. At crop maturity in the $4^{\text {th }}$ week of September, plants were assessed for the severity of stem infection on a scale where $0,1,2,3$, and 4 represented $0 \%, 1-5 \%$, $6-25 \%, 26-50 \%$, and $>50 \%$ of the stem bearing pycnidia of Dpc and Dps. A disease index (DSI) was calculated with Eq. [2]

$$
\mathrm{DSI}=\frac{\left(\sum_{\mathrm{nk}}\right) \times 100}{4 \mathrm{~N}}
$$

where $\mathrm{k}=$ severity rating number ( 0 to 4 ), $\mathrm{n}=$ number of plants with that rating number, and $N=$ number of plants assessed. Plants were hand harvested and mechanically threshed. Total seed yield and 1000 -seed wt were adjusted to $13 \%$ seed moisture content. Weight of seed per row was converted to $\mathrm{kg} \mathrm{ha}^{-1}$ based on a spacing of $0.53 \mathrm{~m}$ between rows. The incidence of contamination of harvested seed by Dpc and Dps in trials 3 and 4 was assessed from 100 seed per replicate as described above.

\section{Data analysis}

Analysis of variance was conducted (SAS Institute 1988). When the F test showed significant treatment effects, means were separated by the least significant difference test $(P=0.05)$. Correlation analyses were conducted by the CORR procedure (SAS Institute 1988).

\section{RESULTS}

Six seed lots were contaminated with Dpc and Dps, and three with PI (Table 1). The fungi isolated matched the descriptions provided by Sinclair and Backman (1989). The levels of contamination by Dpc and Dps within a seed lot were generally similar (5-19\%) except for one seed lot with 76\% Dpc and 8\% Dps. PI was much less common (0-2\%). Two shrivelled seed lots ( 1 and 5 ) had the highest levels of contamination but shrivelled and smooth lots of cV. KG-30 had similar levels of contamination. The incidence of contamination by Dpc and Dps was therefore not consistently related to visual appearance of the seed.

EC50 values ( $m g$ product $\mathrm{L}^{-1}$ ) ranged from 0.4 (Thiram 75WP) to 9.2 (UB!-2467) for Dpc, and from 0.3 (Thiram 75WP) to 48.5 (Captan) for Dps (Table 3). The absolute and relative toxicities of products other than Benlate, UBI-2467, and Captan were similar for both fungi. The products most toxic to both fungi (EC50 $\leq 2.0)$ were Thiram 75WP, Vitaflo-280, UBI-2393, Vitavax P, Thiram 320F, and Anchor. Within each fungus, the calculated toxicities of thiram in Thiram 75WP and Thiram 320F were identical, and toxicities of carbathiin in UBI-1373 and Vitaflo-250 differed by 0.4 and $0.9 \mathrm{mg}$ a.i. $\mathrm{L}^{-1}$ for Dps and $\mathrm{Dpc}$, respectively. 
Pycnidia of both Dpc and Dps were isolated from stems in the field trials. Accordingly, the term disease index is used to describe the degree of infection by one or both pathogens, rather than stem canker or stem blight, which are exclusively used with reference to Dpc and Dps, respectively (Sinclair and Backman 1989).

In trials 1 and 2, analysis of variance showed significant effects of seed lot and fungicide treatment on emergence, stand at harvest, disease index, and yield, but not 1000-seed weight. In the absence of seed treatment, yields within a cultivar were higher and disease indexes were lower in plants grown from smooth seed than in plants grown from shrivelled seed (Table 4). Treatment of shrivelled seed (lots 1 and 3) with Vitaflo-280 increased emergence $(12-46 \%)$, stand at harvest $(12-48 \%)$ and yield $(11-29 \%)$, and reduced disease index $(42-56 \%)$. Seed weight of lot 1 was also increased slightly (2.7\%). Treatment of smooth seed (lots 2 and 4) did not affect plant productivity or disease index. Crops grown from treated shrivelled seed and from treated or untreated smooth seed produced comparable yields and disease indexes.

All fungicides tested in trial 3 increased emergence, stand at harvest and yield, and decreased the disease index and the incidence of harvested seed contaminated

Table 3. Concentration of fungicidal product required to inhibit growth of Diaporthe phaseolorum var. caulivora (Dpc) and D. phaseolorum var. sojae (Dps) by $50 \%$ (EC50)

\begin{tabular}{lrrrrr}
\hline & \multicolumn{2}{c}{$\begin{array}{c}\text { Product EC50 } \\
\left(\mathrm{mg} \mathrm{L}^{-1}\right)\end{array}$} & & $\begin{array}{c}\text { Active ingredient EC50 } \\
\text { (mg L-1) }\end{array}$ \\
\cline { 2 - 5 } Product & Dpc & Dps & Dpc & Dps \\
\hline Thiram 75WP & 0.4 & 0.3 & 0.3 & 0.2 \\
Thiram 320F & 1.0 & 0.7 & 0.3 & 0.2 \\
UBI-1373 & 2.4 & 1.1 & 1.8 & 0.9 \\
Vitaflo-250 & 3.6 & 1.8 & 0.9 & 0.5 \\
Benlate 50WP & 5.4 & 1.3 & 2.7 & 0.7 \\
Captan & 3.3 & 48.5 & 1.7 & 24.3 \\
Vitaflo-280 & 0.5 & 0.4 & -- & -- \\
Vitavax P & 0.5 & 1.0 & -- & -- \\
Anchor & 0.6 & 1.4 & -- & - \\
UBI-2467 & 9.2 & 2.1 & -- & - \\
UBI-2393 & 1.0 & 0.9 & - & - \\
\hline
\end{tabular}

Table 4. Effect of seed quality and seed treatment with Vitaflo-280 on productivity of soybean and severity of stem disease caused by Diaporthe phaseolorum

\begin{tabular}{|c|c|c|c|c|c|c|}
\hline $\begin{array}{l}\text { Seed lot and } \\
\text { appearancet }\end{array}$ & Treatment & $\begin{array}{l}\text { Emergence§ } \\
\text { (No. of plants) }\end{array}$ & $\begin{array}{c}\text { Stand at } \\
\text { harvest§ } \\
\text { (No. of plants) }\end{array}$ & $\begin{array}{c}\text { Disease } \\
\text { index }\end{array}$ & $\begin{array}{c}\text { Yield } \\
\left(\mathrm{kg} \mathrm{ha}^{-1}\right)\end{array}$ & $\begin{array}{c}1000 \text {-seed wt } \\
(\mathrm{g})\end{array}$ \\
\hline \multicolumn{7}{|l|}{ Trial 1} \\
\hline 1 shrivelled & Control & $44.8 \mathrm{~b} \ddagger$ & $42.0 \mathrm{~b}$ & $36.5 \mathrm{~b}$ & $1691 \mathrm{~b}$ & $177 \mathrm{~b}$ \\
\hline 1 shrivelled & Vitaflo-280 & $83.3 \mathrm{a}$ & $80.0 \mathrm{a}$ & $16.0 \mathrm{a}$ & $2383 a$ & $182 \mathrm{a}$ \\
\hline 2 smooth & Control & $74.8 \mathrm{a}$ & $72.3 \mathrm{a}$ & $16.0 \mathrm{a}$ & $2262 \mathrm{a}$ & $187 a$ \\
\hline 2 smooth & Vitaflo-280 & $84.8 \mathrm{a}$ & $83.3 \mathrm{a}$ & $14.5 \mathrm{a}$ & $2413 a$ & $187 a$ \\
\hline \multicolumn{7}{|l|}{ Trial 2} \\
\hline 3 shrivelled & Control & $57.3 \mathrm{~b}$ & $56.0 \mathrm{~b}$ & $32.5 \mathrm{~b}$ & $1585 b$ & $138 \mathrm{a}$ \\
\hline 3 shrivelled & Vitaflo-280 & $65.0 \mathrm{a}$ & $63.3 \mathrm{a}$ & $19.0 \mathrm{a}$ & $1776 \mathrm{a}$ & $141 \mathrm{a}$ \\
\hline 4 smooth & Control & $80.0 \mathrm{a}$ & $78.0 \mathrm{a}$ & $13.5 \mathrm{a}$ & $2191 \mathrm{a}$ & $139 \mathrm{a}$ \\
\hline 4 smooth & Vitaflo-280 & $80.3 \mathrm{a}$ & $78.3 \mathrm{a}$ & $10.5 \mathrm{a}$ & $2217 a$ & $142 \mathrm{a}$ \\
\hline
\end{tabular}

† Seed lots described in Table 1.

$\S$ Plants per 100 seed sown.

$\mp$ Means in the same column within a trial followed by the same letter are not significantly different $(P=0.05)$ according to an LSD test. 
by Dps (Table 5). Seed weight was increased by Vitaflo-280 and Vitavax $P$, and incidence of contamination of harvested seed by Dpc was reduced by UBI2467. In trial 4, seed treatment did not affect plant productivity or disease index (Table 5). Four treatments reduced the incidence of Dpc in harvested seed and three increased the incidence of Dps. Products that consistently ranked high in reducing the disease index and in increasing yield in these two trials were Vitaflo280, Vitavax P, Thiram 320F, and Anchor.

Pearson correlation coefficients relating parameters of plant development and disease were determined for trials 3 and 4 (Table 6). Disease index was negatively correlated with emergence and stand, and positively correlated with incidence of $D p s$ in harvested seed in both trials, and negatively correlated with yield in trial 3 . In addition, yield was positively correlated with both emergence and stand, and emergence was positively correlated with stand in both trials. Significant $(P==0.05)$ Spearman coefficients for correlation of rank order were obtained for fungicide effects (excluding controls) on disease index in trials 3 and $4(r=0.70)$, for toxicity of fungicides to Dpc and Dps in vitro $(r=0.77)$, and for disease control in trial 4 in relation to toxicity of fungicides in vitro to $D p c(r=0.78)$ and $D p s(0.70)$. When UBI2467 was excluded from the analysis, disease control in trial 3 was also correlated with toxicity of fungicides in vitro to $\operatorname{Dpc}(r=0.65)$ and $\operatorname{Dps}(r=0.61)$.

Table 5. Effect of seed treatment with 11 fungicidal products on productivity of soybean, severity of stem disease, and contamination of harvested seed by Diaporthe phaseolorum var. caulivora (Dpc) and D. phaseolorum var. sojae (Dps) in trials 3 and 4

\begin{tabular}{|c|c|c|c|c|c|c|c|}
\hline \multirow[b]{2}{*}{ Treatment } & \multirow{2}{*}{$\begin{array}{l}\text { Emergence§ } \\
\text { (No. of plants) }\end{array}$} & \multirow{2}{*}{$\begin{array}{c}\text { Stand at } \\
\text { harvest§ } \\
\text { (No. of plants) }\end{array}$} & \multirow{2}{*}{$\begin{array}{l}\text { Disease } \\
\text { index } \|\end{array}$} & \multirow{2}{*}{$\begin{array}{c}\text { Yield } \\
\left(\mathrm{kg} \mathrm{ha}^{-1}\right)\end{array}$} & \multirow{2}{*}{$\begin{array}{c}\text { 1000-seed wt } \\
(\mathrm{g})\end{array}$} & \multicolumn{2}{|c|}{$\begin{array}{c}\text { Contarninated } \\
\text { seed at harvest } \\
(\%)\end{array}$} \\
\hline & & & & & & $\mathrm{Dpc}$ & Dps \\
\hline \multicolumn{8}{|l|}{ Trial $3 t$} \\
\hline Anchor & $69.0 \mathrm{ab} \ddagger$ & $67.5 a b$ & $16.0 \mathrm{ab}$ & $2314 a$ & $177 \mathrm{ab}$ & $15 a b$ & $4 b$ \\
\hline Benlate 50WP & $64.5 a b$ & $63.8 \mathrm{ab}$ & $19.0 \mathrm{ab}$ & $2272 a$ & $181 a b$ & $9 a b$ & $8 b$ \\
\hline Captan 50WP & $58.8 b$ & $55.5 b$ & $24.0 \mathrm{~b}$ & $2006 b$ & $173 a b$ & $14 a b$ & $7 \mathrm{~b}$ \\
\hline Thiram 320F & $76.5 \mathrm{a}$ & $72.3 \mathrm{a}$ & $15.5 \mathrm{ab}$ & $2276 a$ & $177 a b$ & $14 a b$ & $3 b$ \\
\hline Thiram 75WP & $74.0 \mathrm{ab}$ & $68.8 \mathrm{ab}$ & $16.0 \mathrm{ab}$ & $2444 a$ & $177 \mathrm{ab}$ & $9 a b$ & $8 b$ \\
\hline UBI-1373 & $62.3 a b$ & $60.8 a b$ & $16.0 \mathrm{ab}$ & $2182 a b$ & $179 a b$ & $16 a b$ & $7 b$ \\
\hline UBI-2393 & $74.0 \mathrm{ab}$ & $72.0 \mathrm{ab}$ & $22.5 \mathrm{~b}$ & 2092 b & $170 \mathrm{~b}$ & $8 a b$ & $4 \mathrm{~b}$ \\
\hline UBI-2467 & $75.0 \mathrm{a}$ & $72.5 \mathrm{a}$ & $14.0 \mathrm{ab}$ & $2259 a$ & $177 \mathrm{ab}$ & $7 \mathrm{~b}$ & $6 b$ \\
\hline Vitaflo-250 & $70.8 \mathrm{ab}$ & $70.5 \mathrm{ab}$ & $18.0 \mathrm{ab}$ & $2050 \mathrm{~b}$ & $178 a b$ & $11 a b$ & $9 b$ \\
\hline Vitaflo-280 & $76.0 \mathrm{a}$ & 73.3 a & $10.5 \mathrm{a}$ & $2353 a$ & 185 a & $13 a b$ & $6 b$ \\
\hline Vitavax $P$ & $72.8 a b$ & $71.8 \mathrm{a}$ & $15.5 \mathrm{ab}$ & $2315 a$ & $183 a$ & $15 a b$ & $4 b$ \\
\hline Control & $41.0 \mathrm{C}$ & $40.5 \mathrm{C}$ & $32.0 \mathrm{c}$ & $1523 c$ & $172 b$ & $17 \mathrm{a}$ & $19 \mathrm{a}$ \\
\hline \multicolumn{8}{|l|}{ Trial 4} \\
\hline Anchor & $68.8 \mathrm{a}$ & $66.8 \mathrm{a}$ & $7.5 \mathrm{a}$ & $2273 a$ & $173 a b$ & $12 \mathrm{a}$ & $12 a b$ \\
\hline Benlate 50WP & $59.3 a$ & $57.5 \mathrm{a}$ & $13.1 \mathrm{ab}$ & $2140 a$ & $167 b$ & $15 a b$ & $16 b$ \\
\hline Captan 50WP & $57.5 \mathrm{a}$ & $54.8 \mathrm{a}$ & $15.6 \mathrm{~b}$ & $1885 a$ & $173 a b$ & $19 a b$ & $20 \mathrm{~b}$ \\
\hline Thiram 320F & $65.5 \mathrm{a}$ & $63.5 \mathrm{a}$ & $6.9 \mathrm{a}$ & $2119 a$ & $174 a b$ & $22 a b$ & $6 a$ \\
\hline Thiram 75WP & $62.3 \mathrm{a}$ & $59.0 \mathrm{a}$ & $9.4 a b$ & $2045 a$ & $169 \mathrm{~b}$ & $18 a b$ & $7 \mathrm{a}$ \\
\hline UBI-1373 & 59.8 a & $58.0 \mathrm{a}$ & $9.4 a b$ & 1921 a & $173 a b$ & $16 a b$ & $8 a$ \\
\hline UBI-2393 & $60.3 a$ & $56.5 a$ & $10.0 \mathrm{ab}$ & 2052 a & $176 \mathrm{a}$ & $22 a b$ & $16 \mathrm{~b}$ \\
\hline UBI-2467 & $60.3 a$ & $55.5 a$ & $11.3 a b$ & 2033 a & 177 a & $29 \mathrm{~b}$ & $5 a$ \\
\hline Vitaflo-250 & $55.5 \mathrm{a}$ & $53.3 \mathrm{a}$ & $10.6 a b$ & 1817 a & $172 a b$ & $11 \mathrm{a}$ & $11 a b$ \\
\hline Vitaflo-280 & $66.0 \mathrm{a}$ & $64.8 \mathrm{a}$ & $5.6 a$ & $2065 a$ & 178 a & $11 \mathrm{a}$ & $6 a$ \\
\hline Vitavax P & $66.8 \mathrm{a}$ & $66.3 \mathrm{a}$ & $6.3 \mathrm{a}$ & $2011 a$ & $175 a b$ & $12 \mathrm{a}$ & $5 a$ \\
\hline Control & $52.8 \mathrm{a}$ & $49.5 \mathrm{a}$ & $14.4 \mathrm{ab}$ & $1735 a$ & $172 a b$ & $31 \mathrm{~b}$ & $9 a$ \\
\hline
\end{tabular}


Table 6. Pearson coefficients of correlation relating emergence, stand, disease index, yield, seed weight and contamination of seed at harvest by Diaporthe phaseolorum var. caulivora (Dpc) and $D$. phaseolorum var. sojae (Dps) in soybean seed treatment trials 3 and 4

\begin{tabular}{|c|c|c|c|c|c|c|c|c|c|c|c|c|}
\hline & \multirow{2}{*}{\multicolumn{2}{|c|}{ Stand }} & \multirow{2}{*}{\multicolumn{2}{|c|}{ Disease index }} & \multirow{2}{*}{\multicolumn{2}{|c|}{ Yield }} & \multirow{2}{*}{\multicolumn{2}{|c|}{ Seed weight }} & \multicolumn{4}{|c|}{ Contaminated seed } \\
\hline & & & & & & & & & \multicolumn{2}{|c|}{$\mathrm{Dpc}$} & \multicolumn{2}{|c|}{ Dps } \\
\hline & Trial 3 & Trial 4 & Trial 3 & Trial 4 & Trial 3 & Trial 4 & Trial 3 & Trial 4 & Trial 3 & Trial 4 & Trial 3 & Trial 4 \\
\hline Emergence & $0.99^{*}$ & $0.98^{*}$ & $-0.84^{*}$ & $-0.84^{*}$ & $0.85^{*}$ & $0.82^{*}$ & 0.41 & 0.33 & -0.53 & -0.48 & $-0.85^{*}$ & -0.36 \\
\hline Stand & -- & -- & $-0.84^{*}$ & $-0.85^{*}$ & $0.83^{*}$ & $0.76^{*}$ & 0.45 & -0.27 & -0.53 & $-0.59 *$ & $-0.84^{*}$ & -0.35 \\
\hline Disease index & -- & -- & -- & -- & $-0.90^{*}$ & -0.54 & $-0.75^{*}$ & -0.44 & 0.25 & 0.51 & $0.72^{*}$ & $0.63^{*}$ \\
\hline Yield & -- & -- & -- & -- & -- & -- & $0.61^{*}$ & 0.03 & -0.38 & -0.33 & $-0.80^{*}$ & -0.04 \\
\hline Seed weight & -- & -- & -- & -- & -- & -- & -- & -- & 0.09 & 0.10 & -0.29 & -0.35 \\
\hline $\mathrm{Dpc}$ & -- & -- & -- & -- & -- & -- & -- & -- & -- & -- & 0.27 & -0.07 \\
\hline
\end{tabular}

* Coefficients marked with an asterisk are significant $(P=0.05)$. 


\section{DISCUSSION}

The study showed that application of fungicide to soybean seed contaminated with Dpc and Dps can increase plant stand and yield and decrease disease index. The fungicide Vitaflo-280 was tested in four trials and significantly increased yield and reduced disease index in three. A further 10 products were tested in trials 3 and 4 and all were effective in trial 3. Although few significant effects were observed in trial 4 , the rank orders of effectiveness of products in reducing disease were similar in trials 3 and 4 . The results of the four trials show that effective active ingredients were thiram, carbathiin, benomyl and captan and that the most effective commercial formulations were Vitaflo-280, VitavaxP, Anchor, and Thiram $320 \mathrm{~F}$.

Although the in vitro test of toxicity was conducted only once and on one isolate each of Dpc and Dps, there is evidence that the data fairly represent the sensitivity of the two fungi to the products. First, the rank order of toxicity of the products in vitro to Dpc and Dps was significantly correlated with rank order of disease control in trial 4 when all products were considered, and in trial 3 with the exception of UBI-2467. These observations are consistent with the assumption that effectiveness in the field depends upon toxicity of the products to a range of genotypes of both fungi. Second, the data were internally consistent. The in vitro toxicities of carbathiin and thiram were scarcely or not affected by the product in which they were formulated. However, there were indications that formulation affected disease control in the field. Three products (Vitaflo-280, Anchor, and UBI2467) contained both carbathiin and thiram. According to an LSD test, these products reduced disease equally. Nevertheless, Vitaflo-280 consistently ranked higher than the other two products even though, at the rates used, it provided the smallest amounts of both active ingredients to seed.

The effect of seed treatment on yield was related to the visual appearance of the seed rather than the level of contamination by Dpc and Dps. In trials 1 and 2, treatment of shrivelled seed with
Vitaflo-280 increased yields to match those produced by untreated smooth seed with similar levels of contamination. Treatment of contaminated smooth seed, however, did not increase yield. Similarly, yield was increased and disease index was reduced by all seed treatments in trial 3 sow $n$ with shrivelled seed but not by any fungicide in trial 4 sown with smooth seed. The physiological status of smooth and shrivelled seed was not determined. However, shrivelled seed treated with fungicide produced yields that were $30 \%$ higher than those from untreated shrivelled seed and equivalent to yields produced from unprotected smooth seed (trials 1 and 2). Similarly, yields from shrivelled seed in trial 3 were increased up to $50 \%$ by seed treatment. This indicates that application of fungicide facilitated the expression of the inherent viability of the seed. Seed treatment was beneficial only when seed was of visually poor quality. In this study, a test of the incidence of contamination would have been insufficient to determine the need for seed treatment. We conclude that seed treatment provides a means of obtaining a satisfactory yield from seed that is viable but would produce a poor crop as a result of contamination by Dpc and Dps.

Although numerous studies have shown the value of seed treatments for improving stand and yield of soybean (Bolkan etal. 1976; Chamberlain and Gray 1974; Dhingra and Muchovej 1982; Ellis et al. 1975; Ferriss et al. 1987; Hildebrand and Koch 1947, 1950), this appears to be the first report showing a relation between effectiveness of seed treatment and visual appearance of seed with comparable levels of contamination by Dpc and Dps. Further studies on the effect of severity of seed infection on germinability and vigour of treated seed lots would be useful in determining the need for seed treatment.

Seed treatment appeared to increase yield by increasing emergence and reducing disease index. In trial 3, yield increases were associated with an increase in emergence and stand at harvest, and a decrease in severity of stem infection by Dpc and Dps. Plant stands $14 \mathrm{~d}$ after seeding and at harvest were essentially identical. Yield was correlated positively with emergence in trials 3 and 4 , and 
negatively with disease index in trial 3 . However, the relative contributions of increased emergence and reduced disease index to improved yield are difficult to assess because emergence and disease index were negatively correlated. The concomitant variation in several plant and disease parameters, as shown by the large number of significant correlation coefficients, precludes ready determination of cause-effect relationships.

Significant correlations between disease index and incidence of contamination of harvested seed by Dps occurred in trials 3 and 4 , and all treatments reduced disease index and contamination of harvested seed by Dps in trial 3. Dps characteristically produces pycnidia abundantly on infected stems (Sinclair and Backman 1989). Our method of rating disease according to coverage of stems by pycnidia would likely reflect the amount of inoculum of Dps on stems. Our data therefore suggest that seed treatments that control stem infection can reduce contamination of harvested seed by Dps and are consistent with the assumption that pycnidiospores of Dps contaminating harvested seed originated from infected stems within the plots. Seed treatments may also have affected the severity of infection of seed or their viability but these possibilities were not tested.

The data support the recommendation to treat soybean seed with products containing thiram and carbathiin (Anchor, Vitaflo-280, or Vitavax P) to control the D-P complex in Ontario (OMAF 1993). They further show that formulations containing thiram alone as the active ingredient can be equally effective.

\section{ACKNOWLEDGMENTS}

Financial support from the Natural Sciences and Engineering Research Council of Canada, the Ontario Ministry of Agriculture, Food and Rural Affairs, and the Canadian International Development Agency through the Black Dragon River Consortium is gratefully acknowledged. Seed lots 1, 3, and 6 were provided by King Agro, Chatham, Ontario, lots 2 and 4 were obtained from the Department of Crop Science, University of Guelph,
Guelph, Ontario, and lot 5 was received from a commercial farm near London, Ontario.

\section{REFERENCES}

Anderson, T.R. 1985. Seed molds of soybean in Ontario and the influence of production area on the incidence of Diaporthe phaseolorumvar. caulivora and Phomopsis sp. Can. J. Plant Pathol. 7 : 74-78.

Bolkan, H.A., A.R. de Silva, and F.P. Cupertino. 1976. Fungi associated with soybean and bean seed and their control in central Brazil. Plant Dis. Rep. 60 : 545-548.

Chamberlain, D.W., and L.E. Gray. 1974. Germination, seed treatment, and microorganisms in soybean seed produced in Illinois. Plant Dis. Rep. $58: 50-54$.

Dhingra, O.D., andJ.J. Muchovej. 1982. Infusion of fungicides into soybean seeds with intact seed coats by organic solvents. Seed Sci. Technol. $10: 109-117$.

Ellis, M.A., M.B. Ilyas, and J.B. Sinclair. 1975. Effects of three fungicides on internally seed borne fungi and germination of soybean seed. Phytopathology 65 : 553556.

Ferriss, R.S., R.E. Stuckey, M.L. Gleason, and M.R. Siegel. 1987. Effects of seed quality, seed treatment, soil source, and initial moisture on soybean seedling performance. Phytopathology 77 : 140-148.

Fisher, N.L., L.W. Burgess, T.A. Toussoun, and P.E. Nelson. 1982. Carnation leaves as a substratum for preserving cultures of Fusarium species. Phytopathology $72: 151-153$.

Hall, R., and X. Guoxing. 1987. Chemical seed treatments to control seed decay and seedling blight of soybean caused by Diaporthe phaseolorum var. caulivora. Phytoprotection $68: 135$.

Hildebrand, A.A., and L.W. Koch. 1947. Soybean diseases in Ontario and effectiveness of seed treatment. Phytopathology 37 : 114124.

Hildebrand, A.A., and L.W. Koch. 1950. Observations on six years' seed treatment of soybean in Ontario. Sci. Agric. 30 : 112118.

McGee,D.C. 1986. Treatment of soybean seeds. Pages 185-200 in K.A. Jeffs (ed.), Seed treatment. BCPC Publications, Surrey, England. 
OMAF. 1993. Field crop recommendations for 1993-1994. Ontario Ministry of Agriculture and Food, Publication no. 296. 96 pp.

SAS Institute Inc. 1988. SAS/STAT user's guide : release 6.03. SAS Institute Inc., Cary, North Carolina. 1029 pp.

Sinclair, J.B., and P.A. Backman. 1989. Compendium of soybean diseases. APS Press, St. Paul, Minnesota. 106 pp.
Wallen, V.R. 1960. A high incidence of Diaporthe phaseolorum occurring in the seed of soybeans from southwestern Ontario. Plant Dis. Rep. $44: 596$.

Wallen, V.R., and W.L. Seaman. 1963. Seed infection of soybean by Diaporthe phaseolorum and its influence on host development. Can. J. Bot. 41 : 13-21. 